\title{
Geotourism and soil quality on trails within Protected Areas in South-East Brazil
}

Luana de Almeida Rangel ${ }^{1}$, Maria do Carmo Oliveira Jorge ${ }^{1}$, Antonio Jose Teixeira Guerra $^{1}$, Michael Augustine Fullen ${ }^{2}$

${ }^{1}$ Department of Geography, Federal University of Rio de Janeiro, Rio de Janeiro, Brazil ${ }^{2}$ Faculty of Science and Engineering, The University of Wolverhampton, Wolverhampton WV1 1LY, UK

Corresponding author: Luana de Almeida Rangel

Acknowledgments The authors thank CNPq (the Brazilian Research Council) and FAPERJ (the Rio de Janeiro Research Council) for financial support.

\begin{abstract}
Geotourism is a growing activity in Brazil, mainly in Protected Areas, where trails are used by both visitors and local people to access geotourist attractions. The use of these trails can have negative impacts when there is inadequate planning and management. This research investigated two geotourist trails; Caixa D 'Aço natural pool trail in Serra da Bocaina National Park (State of Rio de Janeiro) and Água Branca waterfall trail in Serra do Mar State Park (State of São Paulo State). Geodiversity values were assessed at both geosites, adopting the methods of Gray $(2004,2013)$. Soil physico-chemical analyses were conducted on samples from $0-10 \mathrm{~cm}$ depth. The dominant soil texture on Caixa D'Aço natural pool trail is sandy clay loam and on Água Branca trail all samples were coarse sandy loams. Soils on Caixa D'Aco natural pool trail were compact, with a mean bulk density of $1.41 \mathrm{~g} /$ $\mathrm{cm}^{3}$; whereas on Água Branca trail the mean value was $1.19 \mathrm{~g} / \mathrm{cm}^{3}$. The geodiversity values at both sites were similar, except for supporting services, Caixa D'Aço natural pool has a medium value, and Água Branca waterfall has a high value. This paper stresses the importance of geoconservation studies in publicizing the geoheritage of Brazilian Protected areas.
\end{abstract}

Keywords Geotourism, trails, erosion, environmental education, tropical environments, Atlantic forest.

\section{"In nature's infinite book of secrecy,} a little I can read"

William Shakespeare (Anthony and Cleopatra, Act 1, Scene 2, lines 9-10).

\section{Introduction}

Geotourism is a branch of tourist activity which values and encourages the conservation of geological and geomorphological heritage (Dowling 2009, 2010, 2013, Lopes et al. 2011, Gray 2005, 2013, Brilha 2016). This includes elucidating the educational and environmental potential of these environments, with the objective of 
promoting sustainable tourism and geodiversity presentation, interpretation and understanding (Newsome and Dowling 2006, Bento and Rodrigues 2013, Kubaliková 2013, Avelar et al. 2018, Forte et al. 2018).

Most natural areas with potential for the development of geotourism are within Protected Areas ${ }^{1}$ (Bento and Rodrigues, 2013). Thus, a major challenge is to balance public access and environmental conservation. Geotourism plays vital roles in valuing and conserving geological and geomorphological heritage and promoting sustainable development (Newsome and Dowling 2006, Hose 2006, Nascimento et al. 2015, Brilha 2016, Jorge and Guerra 2016, Rangel and Guerra 2018).

Trails are integral components of cultural landscapes and have long been used as communication corridors. In recent decades geotourism has increased in importance (Serrano and Gonzales-Trueba 2005, Conway 2010, Jorge et al. 2016, Jorge 2017, Rangel and Guerra 2018). Trails have multiple functions, including accessing natural environments, nature contemplation, recreation and sporting activities (Cole 1993, Hammett and Cole 1998, Takahashi 1998, Leung and Marion 1999, Magro 1999, Lynn and Brown 2003, Figueiredo et al. 2010).

Trampling can degrade trails (Leung and Marion 1996, Jewell and Hammitt 2000, Marion and Leung 2001). Trail mismanagement can cause soil degradation (i.e. decreased soil quality and capacity as an environmental regulator (Doran and Parkin 1994, Doran and Jones 1996, Lal 1997, Arshad and Martin 2002).

Many studies have investigated soil degradation on trails. Trampling may cause physical degradation, including soil compaction and erosion, chemical and biological depletion, with nutrient and soil organic matter (SOM) losses, and decreased soil faunal activity (Cole and Schreiner 1981; Bright 1986; Cole and Landres 1996; Marion and Cole 1996; Hammitt and Cole 1998; Takahashi 1998; Magro 1999; Kutiel et al. 1999; Nepal 2003; Nepal and Amor-Nepal 2004; Barros 2013; Rangel 2014; Wolf and Croft 2014). The magnitude of the impacts of trampling depends on multiple factors, including environmental conditions and trail use. Several indicators have been used to analyse impacts on trails and multiple changes have been reported in both biotic and abiotic conditions at specific sites (Leung and Marion 1996, Marion and Leung 2001, Conway 2010).

\footnotetext{
${ }^{1}$ The international community uses the term 'Protected Areas.' However, in Brazil, this term encompasses areas that have specific legislation, and are not included in the NCUS (National Conservation Unit System). These include Indigenous Lands, Permanent Preservation Areas of riverbanks and headwaters and rocky coasts. Therefore, we have adopted the term 'Conservation Units,' as used in Brazil.
} 
The planning and management of trails using geodiversity, geotourism and geoconservation concepts have grown in recent decades (Gray 2008, Conway 2010, Jorge et al. 2016, Jorge 2017, Rangel 2018). Investigations of sites and trails of geological interest in Itacolomi State Park (Minas Gerais State) show these trails are geotouristic attractions, which are public resources and contribute to environmental education programmes (Ostanello et al. 2013). Similar roles have been discussed regarding the Campos Gerais National Park (Folmann et al. 2010).

Two Protected Areas (PAs) were selected from the 'Atlantic Forest Biosphere Reserve,' which is the first Brazilian unit within the 'World Biosphere Reserves Network.' It is the largest forest biosphere reserve in the world. The main objectives are the conservation of the biome through implementation of a continuous ecological corridor of coastal Atlantic Forest, linking existing forest fragments (Brasil 2000). They are also part of the 'Serra do Mar Biodiversity Corridor.' The two PAs are situated in an area of great touristic area appeal, especially for coastal attractions. They have two different administrations, Federal (Serra da Bocaina National Park: SBNP), and State (Serra do Mar State Park: SMSP).

Considering the impacts caused by lack of trail planning and management in Protected Areas, it is necessary to assess whether their use causes soil degradation. Therefore, this research analyses soil quality on two geotourist trails, one in SBNP and another in SMSP. Investigations assessed the trampling impacts caused by visitors and evaluated geodiversity qualitative assessment values. The information was conveyed to the Administrations of both Protected Areas, to assist in decision-making regarding geotourism development and measures to reduce environmental degradation.

\section{Materials and methods}

Infrastructure measures, trail interpretations and access were analysed following the guidelines of Moreira (2010). Geodiversity services were studied using the procedures of Gray (2013). The first two trails access Caixa D'Aço natural pool, a geodiversity site located in SBNP, Paraty Municipality, Rio de Janeiro State $(R J)$. The other trail accesses Água Branca Waterfall, a geosite within SMSP, Ubatuba Municipality, São Paulo State (SP) (Fig. 1). 


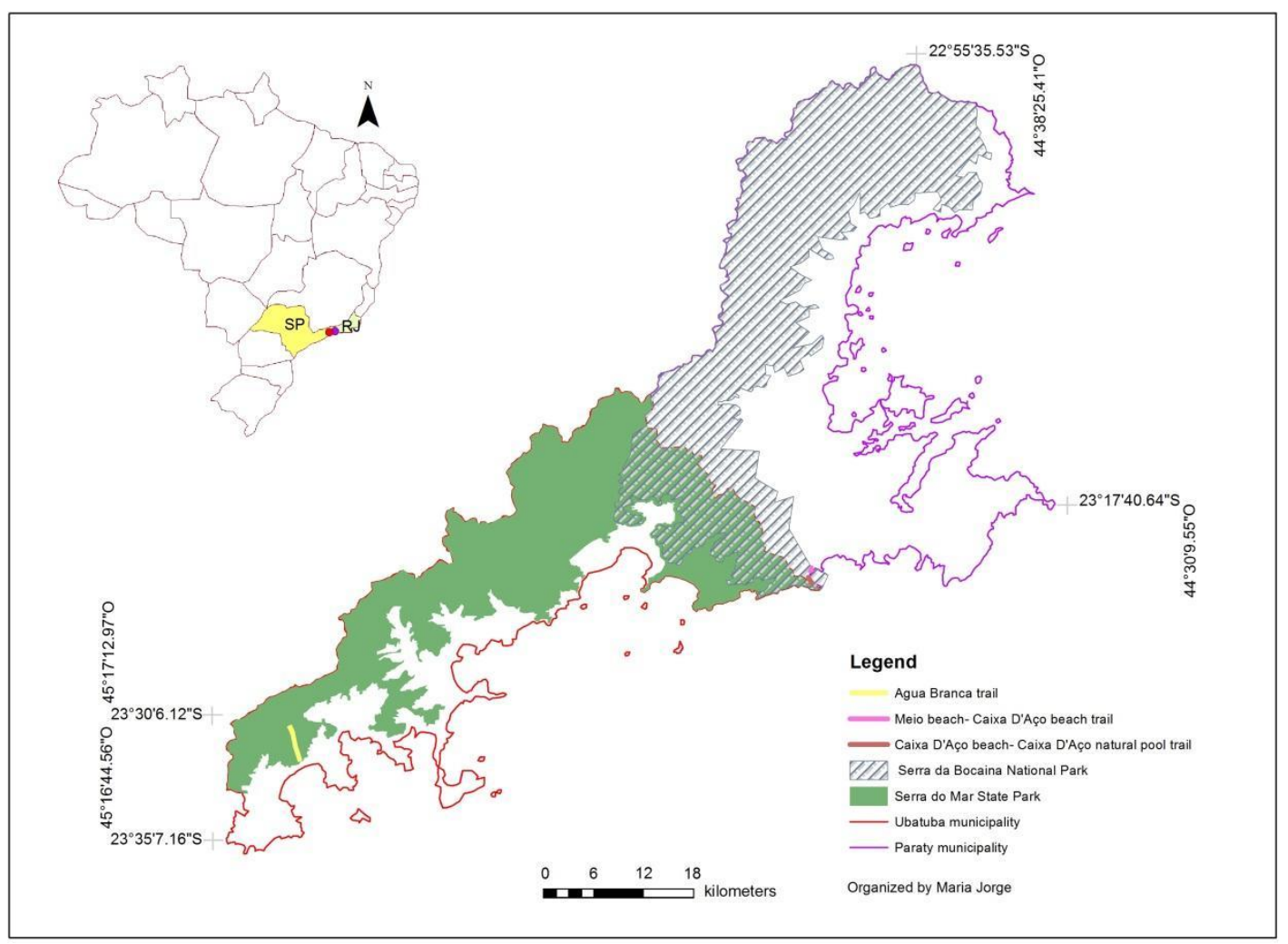

Fig. 1. Study area. (Figure prepared by Maria do Carmo Oliveira Jorge, 2018).

Surveys of infrastructure (e.g. the presence of steps, guardrails, handrails, rubbish bins and signboards) assisted analysis of geotourism potential. Interpretative features were also surveyed (e.g. explanatory posters, folders and field guides). Surveys were conducted both within the geodiversity sites in general and along the trails in particular (Moreira 2010). The relative strengths and weaknesses of geotourism development were evaluated.

Geodiversity values were measured based on ecosystem services (Gray 2005). These values include: intrinsic value, cultural value, aesthetic value, economic value, functional value and scientific/educational value (Gray 2013) (Table 1). 
Table 1. Geodiversity services and the main evaluated attributes

\begin{tabular}{|c|c|c|}
\hline Geodiversity Services & Assessed attributes & $\begin{array}{c}\text { Assessment of the } \\
\text { importance of the } \\
\text { geodiversity site for } \\
\text { attributes } \\
\end{array}$ \\
\hline Regulatory services & $\begin{array}{l}\text { Oceanic and atmospheric } \\
\text { processes; ground processes; } \\
\text { flood control; water quantity and } \\
\text { quality. }\end{array}$ & $\begin{array}{l}\text { H: High } \\
\text { M: Medium } \\
\text { L: Low } \\
\text { N: None }\end{array}$ \\
\hline Support services & $\begin{array}{l}\text { Soil processes; provision of } \\
\text { habitats; the earth as a platform; } \\
\text { storage. }\end{array}$ & $\begin{array}{l}\mathrm{H} \\
\mathrm{M} \\
\mathrm{L} \\
\mathrm{N}\end{array}$ \\
\hline Provisioning services & $\begin{array}{l}\text { Food and drink; nutrients and } \\
\text { minerals for healthy growth; } \\
\text { fuels; construction materials; } \\
\text { industrial minerals; ornamental } \\
\text { products; fossils. }\end{array}$ & $\begin{array}{l}\mathrm{H} \\
\mathrm{M} \\
\mathrm{L} \\
\mathrm{N}\end{array}$ \\
\hline Cultural services & $\begin{array}{l}\text { Environmental quality; } \\
\text { geotourism and leisure; cultural, } \\
\text { spiritual and historical } \\
\text { significance; artistic inspiration; } \\
\text { social development. }\end{array}$ & $\begin{array}{l}\mathrm{H} \\
\mathrm{M} \\
\mathrm{L} \\
\mathrm{N}\end{array}$ \\
\hline Knowledge services & $\begin{array}{l}\text { Land history; knowledge of } \\
\text { physical processes; history of } \\
\text { research; } 4 \text { environmental } \\
\text { monitoring; education and } \\
\text { employment. }\end{array}$ & $\begin{array}{l}\mathrm{H} \\
\mathrm{M} \\
\mathrm{L} \\
\mathrm{N}\end{array}$ \\
\hline
\end{tabular}

(Adapted from Gray 2013).

For soil quality analysis, $0-10 \mathrm{~cm}$ depth soil samples were collected at two sites on Meio beach (Caixa D'Aço beach trail, MCT1 and MCT2) and three sites on Caixa D'Aço beach-natural pool trail (NCT3, NCT4, NCT5), situated in SBNP. Soils were sampled at four sites on Água Branca Waterfall trail (ABT) in SMSP.

Soil physical properties (porosity, bulk density and texture) and chemical properties (organic matter and pH) were measured using EMBRAPA (2011) (Brazilian Agricultural Research Corporation) methods. Soil textural classification adopted the United States Department of Agriculture protocols (USDA 2015).

Bulk density was determined using a volumetric cylinder, where soil samples were collected inside a $100 \mathrm{~cm}^{3}$ steel cylinder (EMBRAPA 2011), and then oven-dried 
at $105^{\circ} \mathrm{C}$ for 24 hours in the laboratory. Then samples were allowed to cool and the dry weight was divided by 100 , to determine bulk density $\left(\mathrm{g} / \mathrm{cm}^{3}\right)$.

Soil texture was determined using the EMBRAPA (2011) method, where $10 \mathrm{ml}$ of dispersant and $100 \mathrm{ml}$ of distilled water were added to $20 \mathrm{~g}$ of soil. Then, the mixture was mechanically shaken for 15 minutes and washed in the $0.053 \mathrm{~mm}$ sieve, where sand was retained and the silt+clay fractions were added to a $1000 \mathrm{ml}$ beaker. After a fixed time, $50 \mathrm{ml}$ of water mixed with soil was pipetted to collect the clay fraction, which was oven-dried at $105^{\circ} \mathrm{C}$ for 24 hours. Finally, the sample was sieved using a $0.20 \mathrm{~mm}$ sieve, to separate fine and coarse sand. Data were then plotted on the textural triangle.

Soil porosity represents the total volume of voids within the soil occupied by water and/or air and is directly related to both soil density and compaction. Soil porosity was calculated using the EMBRAPA (2011) technique.

Soil organic matter (SOM) was determined by oxidation with potassium dichromate and three drops of diphenylamine (EMBRAPA 2011). SOM (g/kg) data were converted into soil organic carbon (SOC) using the Van Bemmelen constant of *1.724. Soil pH was determined using $10 \mathrm{~g}$ of fine-earth soil $(<2.0 \mathrm{~mm})$ in $25 \mathrm{ml}$ of distilled water. The mixture was thoroughly shaken and then allowed to stand for one hour. Soil pH was measured using a calibrated digital pH meter (EMBRAPA 2011).

\section{Study area}

\section{Serra da Bocaina National Park}

The two trails that access Caixa D'Aço natural pool (CANP), a geodiversity site located on the Serra da Bocaina National Park coast, are 190 m (MCT trail) and 465 m long (NCT trail). Serra da Bocaina National Park (SBNP) covers 104,000 hectares, of which $\sim 60 \%$ is located in RJ State (Angra dos Reis and Paraty Municipalities) and $\sim 40 \%$ in SP State (São José do Barreiro, Ubatuba and Cunha Municipalities).

Trindade village, where the surveyed trails are located, is part of SBNP and is one of the main local tourist destinations (Conti and Irving, 2014). In addition, due to the scenic beauty of the tourist attractions, several trails are used for geotourism, including the two trails that access Caixa D'Aço natural pool; the trail from the Meio beach to Caixa D'Aço beach (MCT) and Caixa D'Aço beach to the natural pool trail (NCT). Caixa D'Aço natural pool (Fig. 2) is a geodiversity site; which can be defined as " $a$ 
geographically limited place that has pedagogical, cultural and/or tourist value and is, therefore, a geoconservation object" (Brilha 2016, p. 123).
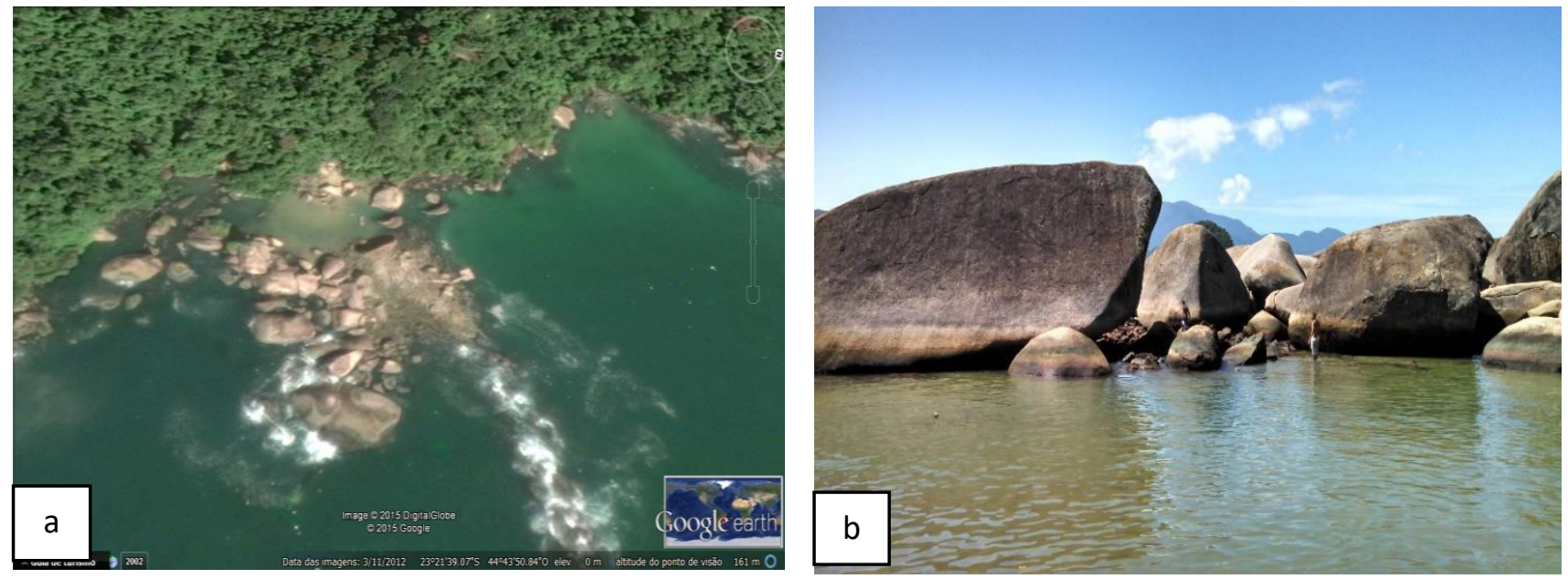

Fig. 2 (a) Aerial view Caixa D'Aço natural pool. Image: Digital Globe (2015). Source: Google Earth. (b) View of the natural pool from the end of the trail. Photo: L.A. Rangel (2014).

The Köeppen climatic classification is humid tropical (MMA 2002, Conti and Irving 2014). Local climate is influenced by relief compartmentalization and altimetric unevenness, which produce spatio-temporal variations in precipitation and temperature patterns. The Serra do Mar has orographic impacts on frontal systems and thus markedly influences the regional rainfall regime.

SBPN is composed of granites and gneisses (Guerra et al. 2013) and is located on the Bocaina Plateau (Ponçano et al. 1980). The Park coast forms part of a 'scarp border' relief unit, with local slopes $>27^{\circ}$ (Ponçano et al. 1980). Local soils have clayey and silty textures, corresponding to associations of Inceptisols, with moderately developed to prominent A horizons (MMA 2002). Coastal vegetation is mainly secondary dense forest, in middle to advanced stages of recovery (MMA 2002).

\section{Serra do Mar State Park}

Ubatuba Municipality $\left(23^{\circ} 26^{\prime} 13^{\prime \prime S}, 45^{\circ} 04^{\prime} 08^{\prime \prime} \mathrm{W}\right)$ covers $712 \mathrm{~km}^{2}$ and the total population is 78,801 (IBGE 2010). The main economic activities are tourism, construction and fishing. Its territory has an elongated southwest-northeast orientation, being $60 \mathrm{~km}$ long and the coastal plain is 5-17 km wide. Serra do Mar mountain range dominates the landscape and lies parallel to the coast (Cruz 1974). 
Granites and gneisses overlie the crystalline basement (Proterozoic-Eopaleozoic and Mesozoic), and Cenozoic sediments are distributed throughout the coastal plain (Hasui et al. 1993). The main soil types are Inceptisols, Oxisols, Entisols and Histosols. Inceptisols are the main soil type in the study area, associated with hilly to mountainous relief and the fluvial plains. Entisols mainly occur on the steep slopes of the Serra do Mar mountain range (SMA-SP 2008).

The Köeppen climatic classification is tropical maritime, being warm and humid, with a mean temperature of $19^{\circ} \mathrm{C}$. Maximum annual rainfall is $\sim 4,000 \mathrm{~mm}$, with an average of $\sim 2,500 \mathrm{~mm}$ (Monteiro 1973; Jorge et al. 2003). These high rainfall amounts are caused by humid tropical maritime airstreams advected from the Atlantic Ocean, which condense when they reach the orographic barrier of the Serra do Mar mountain range (Monteiro 1973). These physical conditions promote the development of Atlantic Forest, which is one of the 34 world 'hotspots' for conservation, due to its high biodiversity and many indigenous species of flora and fauna (Mittermeier et al. 2005).

Serra do Mar State Park is the largest strictly-enforced protection area on the Brazilian coast. It was legally established in 1977, through Decree number 1977/10251, and the legal status was finally approved in 1985. The State Park covers 315,390 ha and encompasses 23 Municipalities in SP, stretching from Ubatuba on the RJ State border, to Pedro de Toledo Municipality, on the Southern coast (SMA-SP 2008).

In Ubatuba, the Parks covers 47,000 ha, some $79.58 \%$ of its total area. It starts from $100 \mathrm{~m}$ high (except in the Picinguaba Sector, where the Park reaches the beach). This Sector encompasses a fishing village, traditional population settlements, sandbars, mangroves and several tourist beaches (SMA-SP 2008). In this region, on the RJ State border, SMSP overlays SBNP, which reaches the sea, protecting Caixa D'Aço beach and natural pool, in Trindade Village, Paraty Municipality. Serra da Bocaina National Park covers $12.7 \%$ of Ubatuba Municipality.

\section{Results and Discussion}

\section{Physico-chemical soil quality on trails}

On Água Branca trail, the main soil type is Entisol (Lithic), which are typically very shallow and stony and lack a B Horizon. On the Caixa D'Aço trails the main soil type is Inceptisol. Here much of the B Horizon has already been eroded. 
The dominant soil texture on Caixa D'Aço natural pool trails is sandy clay loam (MCT 1, MCT 2 and NCT 4) (Table 2). On Água Branca trail all investigated sites had coarse sandy loam textures. Caixa D'Aço natural pool trails had higher clay contents (mean $29 \%$ in MCT 1 and MCT 2) compared to Água Branca trail $(<16 \%)$.

Silt and fine sand fractions are more susceptible to erosion, because they are fine particles and, without adequate management, they are highly erodible (Morgan 2005). Silt plus fine sand contents $>40 \%$ are especially erodible (Fullen and Catt 2004; Morgan 2005; Smets et al. 2011; Rangel and Guerra 2018). Therefore, ABT 2 (48.9\%), NCT 3 $(45.1 \%)$ and NCT $5(40.8 \%)$ are particularly erodible. In contrast, clays promote soil aggregation and thus have low erodibility.

Table 2 Soil texture (0-10 cm depth) on Água Branca trail (SBNP) and Caixa D'Aço natural pool trails (SMSP)

\begin{tabular}{|c|c|c|c|c|c|c|c|}
\hline \multicolumn{2}{|c|}{ Soil collecting sites } & \multirow{2}{*}{$\begin{array}{c}\begin{array}{c}\text { Coarse } \\
\text { sand } \\
(\%)\end{array} \\
61.2\end{array}$} & \multirow{2}{*}{$\begin{array}{c}\begin{array}{c}\text { Fine } \\
\text { sand } \\
(\%)\end{array} \\
14.7\end{array}$} & \multirow{2}{*}{$\begin{array}{l}\text { Silt } \\
(\%)\end{array}$} & \multirow{2}{*}{$\begin{array}{l}\text { Clay } \\
(\%)\end{array}$} & \multirow{2}{*}{$\begin{array}{c}\text { Silt+Fine } \\
\text { sand }(\%)\end{array}$} & \multirow{2}{*}{$\begin{array}{c}\text { Textural class } \\
\text { Coarse Sandy Loam }\end{array}$} \\
\hline & ABT 1 & & & & & & \\
\hline \multirow{4}{*}{$\begin{array}{l}\text { Água } \\
\text { Branca } \\
\text { trail }\end{array}$} & ABT 2 & 43.2 & 13.3 & 35.6 & 7.9 & 48.9 & Coarse Sandy Loam \\
\hline & ABT 3 & 50.1 & 10.2 & 28.6 & 11.1 & 38.8 & Coarse Sandy Loam \\
\hline & ABT 4 & 45.8 & 10.3 & 28.6 & 15.3 & 38.9 & Coarse Sandy Loam \\
\hline & $\begin{array}{c}\text { Mean } \\
\text { trail ground }\end{array}$ & 50.1 & 12.1 & 26.8 & 11.5 & 38.9 & - \\
\hline \multirow{6}{*}{$\begin{array}{c}\text { Caixa } \\
D^{\prime} A c ̧ o \\
\text { natural } \\
\text { pool } \\
\text { trails }\end{array}$} & MCT 1 & 42.8 & 13.3 & 14.7 & 29.2 & 28 & Sandy Clay Loam \\
\hline & MCT 2 & 41.2 & 11.7 & 18.3 & 28.8 & 30 & Sandy Clay Loam \\
\hline & NCT 3 & 28.1 & 10.7 & 34.4 & 26.8 & 45.1 & Clay Loam \\
\hline & NCT 4 & 45.3 & 10.7 & 18.1 & 25.9 & 28.8 & Sandy Clay Loam \\
\hline & NCT 5 & 41.2 & 10.3 & 30.4 & 18.1 & 40.7 & Loam \\
\hline & $\begin{array}{c}\text { Mean } \\
\text { trail ground }\end{array}$ & 39.72 & 11.34 & 23 & 25.6 & 34.6 & - \\
\hline
\end{tabular}

Coarse sand $>0.2$ and $<2.0 \mathrm{~mm}$, fine sand $>0.053$ and $<0.2 \mathrm{~mm}$, silt $>0.002$ and $<0.053$ mm, clay <0.002 mm (Source: EMBRAPA 2011).

Soil porosity values $>45 \%$ indicate low soils erodibility, $35-45 \%$ indicates medium erodibility and $<35 \%$ represents high erodibility (An et al. 2013, Rangel and Guerra 2018). Soil porosity results ranged between medium erodibility on Caixa D'Aço 
natural pool trails (mean $42.1 \%$ on trail ground) and low erodibility on Água Branca trail sites (mean 49,8\% on trail ground) (Table 3).

Table 3 Soil pore arrangement, density and chemical properties $(0-10 \mathrm{~cm}$ depth) on Água Branca trail (SBNP) and Caixa D'Aço natural pool trails (SMSP)

\begin{tabular}{|c|c|c|c|c|c|}
\hline \multicolumn{2}{|c|}{ Soil collecting sites } & \multirow{2}{*}{$\begin{array}{c}\begin{array}{c}\text { Bulk density } \\
\left(\mathrm{g} / \mathbf{c m}^{\mathbf{3}}\right)\end{array} \\
1.2\end{array}$} & \multirow{2}{*}{$\begin{array}{c}\text { Porosity (\%) } \\
51.6\end{array}$} & \multirow{2}{*}{$\begin{array}{c}\begin{array}{c}\text { Soil organic } \\
\text { matter }(\%)\end{array} \\
6.2\end{array}$} & \multirow{2}{*}{$\frac{\mathbf{p H}}{3.7}$} \\
\hline \multirow{5}{*}{$\begin{array}{c}\text { Água } \\
\text { Branca } \\
\text { trail }\end{array}$} & ABT1 & & & & \\
\hline & ABT2 & 1.2 & 49.9 & 12.4 & 3.7 \\
\hline & ABT3 & 1.3 & 45.0 & 7.5 & 3.9 \\
\hline & ABT4 & 1.1 & 52.6 & 8.2 & 3.7 \\
\hline & $\begin{array}{l}\text { Mean } \\
\text { trail ground }\end{array}$ & 1.2 & 49.8 & 8.6 & 3.8 \\
\hline \multirow{6}{*}{$\begin{array}{c}\text { Caixa } \\
\text { D'Aço } \\
\text { natural } \\
\text { pool } \\
\text { trails }\end{array}$} & MCT1 & 1.4 & 43.3 & 5.8 & 6.9 \\
\hline & MCT2 & 1.4 & 40.7 & 5.0 & 5.4 \\
\hline & NCT3 & 1.4 & 43.2 & 4.6 & 5.6 \\
\hline & NCT4 & 1.4 & 44.1 & 6.3 & 6.4 \\
\hline & NCT5 & 1.4 & 39.4 & 3.4 & 4.2 \\
\hline & $\begin{array}{l}\text { Mean } \\
\text { trail ground }\end{array}$ & 1.4 & 42.1 & 5.0 & 5.7 \\
\hline
\end{tabular}

Reichert et al. (2003) proposed critical bulk density values for soil quality on different textural classes: $1.3-1.4 \mathrm{~g} / \mathrm{cm}^{3}$ for clay soils, $1.4-1.5 \mathrm{~g} / \mathrm{cm}^{3}$ for clay loam soils and $1.7-1.8 \mathrm{~g} / \mathrm{cm}^{3}$ for sandy loam soils. Bulk density results on the Caixa D'Aco natural pool trails (Table 3 ) had a mean value of $1.4 \mathrm{~g} / \mathrm{cm}^{3}$, indicative of a compact soil (Fullen and Catt 2004). On Água Branca trail the mean was $1.2 \mathrm{~g} / \mathrm{cm}^{3}$, which is a low value.

Fullen and Catt (2004) consider mean bulk density values of $1.0-1.40 \mathrm{~g} / \mathrm{cm}^{3}$ as indicative of low to moderate compaction and values $>1.40 \mathrm{~g} / \mathrm{cm}^{3}$ as indicative of compact soils. However, following the thresholds proposed by Reichert et al. (2003) and comparing bulk density and textural classes, NCT 3 has a critical bulk density, as texture is clay loam and bulk density is $1.4 \mathrm{~g} / \mathrm{cm}^{3}$.

High soil bulk density and low pore values contribute to lower infiltration rates, increasing runoff and thus accelerating soil erosion (Morgan 2005; An et al. 2013; Pereira et al. 2016; Rangel and Guerra 2018). Therefore, high bulk density values on MCT and NCT are probably due to high trampling intensity. Trampling compacts the 
soil and decreases macropore size and inter-connectivity and thus impedes soil drainage (Fig. 3).

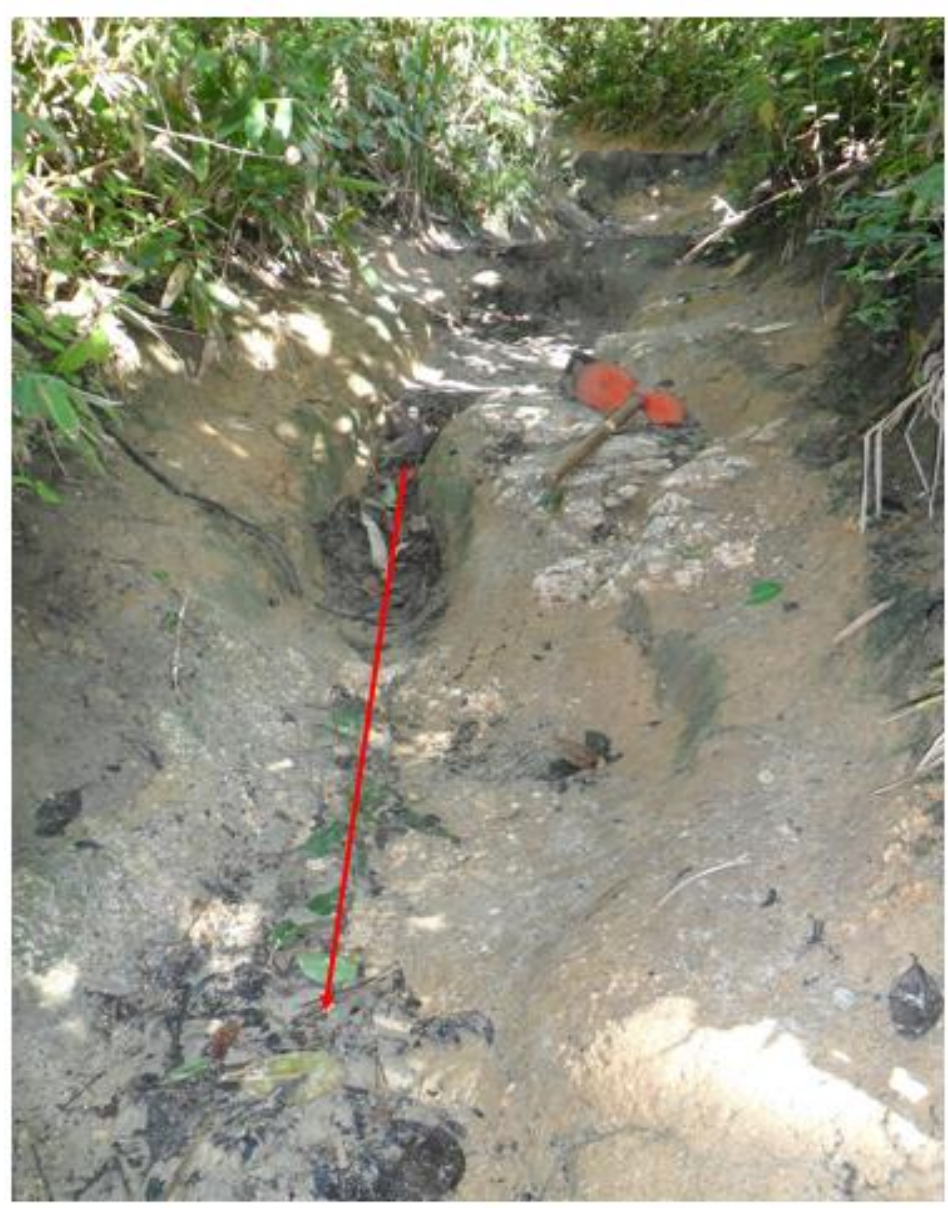

Fig. 3. Rill on Meio-Caixa D'Aço trail. Photo: L.A. Rangel (2016).

On both study areas soil $\mathrm{pH}$ values are acidic, which is typical of tropical rainforest soils, where intense chemical weathering occurs. Soil pH is particularly low on Água Branca trail, with a mean of 3.8 and values ranging between 3.7-3.9. On Caixa $D^{\prime} A c ̧ o$ trail the mean $\mathrm{pH}$ is 5.7 and ranges between 4.2-6.9 (Table 3).

On Caixa D'Aço trail mean soil organic matter (SOM) content was 5\% and ranged between 3.4-6.3\%. SOM values were higher on Água Branca trail (mean 8.5\%, range $6.2-12.4 \%$ ), probably due to the presence of more of plant litter.

Soil erosion on Água Branca trail is mainly due to shallow mass movements; which undercut the trail edges. Usually, erosion features on trails tend to widen paths (Fig. 4 a,b). These mass movements on trail edges may pose a risk to visitors, since the trail is on a steep slope. All investigated trails are widening due to users taking shortcuts. Trail widths usually range between 0.4-1.3 m. 

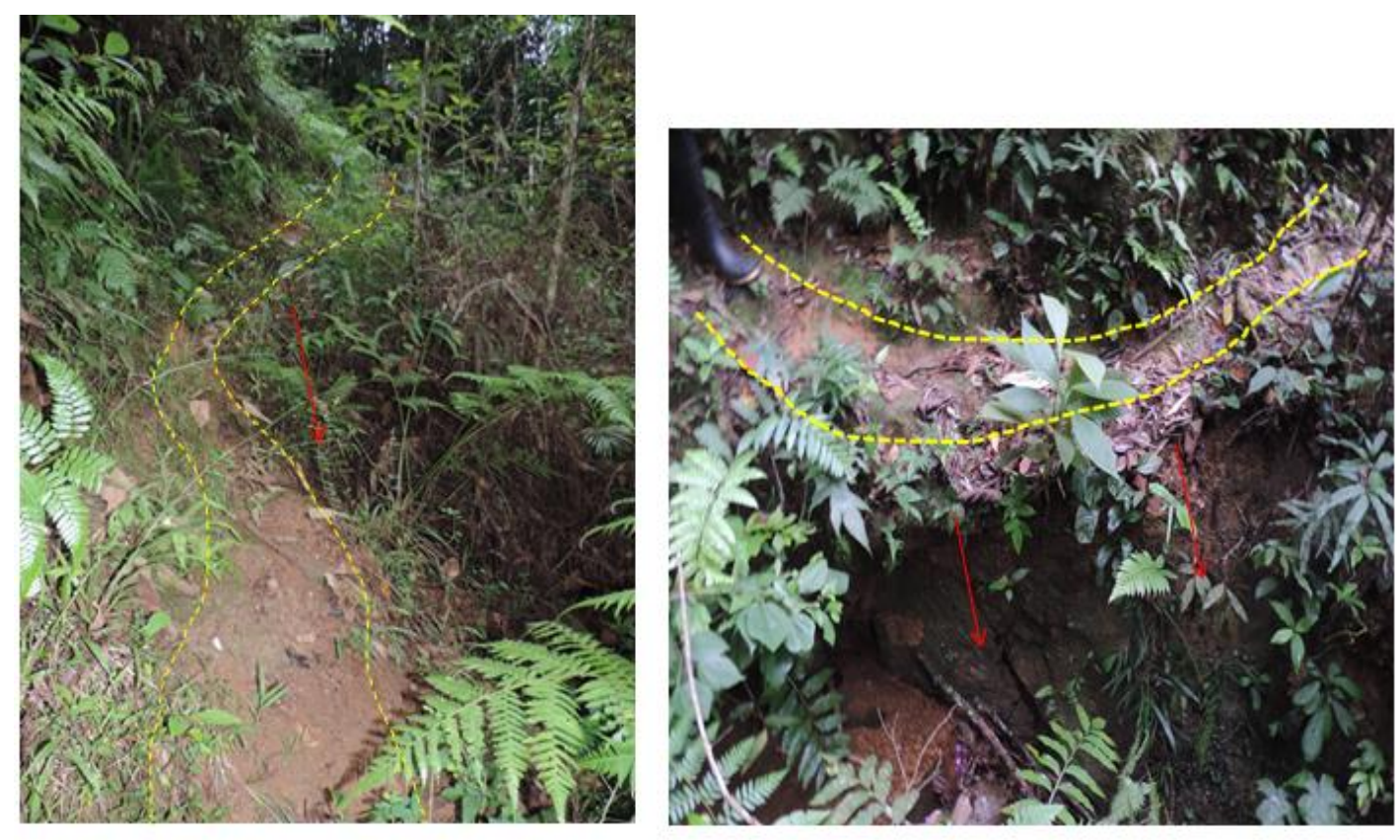

Fig. 4 a,b. Narrow Água Branca trail, showing undercutting on the trail edge. Photo: M.C.O. Jorge (2014).

\section{Geotourism potential and geodiversity values}

Geodiversity assessment values were very similar results between the two study areas, being different only for Economic and Scientific/Educational values (Table 4). The higher economic value of Caixa D'Aço natural pool (CANP) is because there are boat transport services and tourist guides on the trails, whereas on Água Branca trail there are no economic services.

Scientific and educational values were medium for CANP, since it is possible to observe chemical weathering processes. These include spheroidal weathering and processes associated with climatic dynamics through geological time, illustrated by blocks that form the pool (Fig. 5). 
Table 4 Geodiversity value of Caixa D'Aço natural pool trails (SBNP) and Água Branca trail (SMSP)

\begin{tabular}{ccccccc}
\hline Values & Intrinsic & $\begin{array}{c}\text { Cult- } \\
\text { ural }\end{array}$ & $\begin{array}{c}\text { Aesth- } \\
\text { etic }\end{array}$ & Economic* & $\begin{array}{c}\text { Function- } \\
\text { al }\end{array}$ & $\begin{array}{c}\text { Scientific/ } \\
\text { Education- } \\
\text { al }\end{array}$ \\
\hline $\begin{array}{c}\text { Caixa D'Aço } \\
\text { natural pool } \\
\text { Agua Branca } \\
\text { trail }\end{array}$ & $\mathrm{H}$ & $\mathrm{H}$ & $\mathrm{H}$ & $\mathrm{H}$ & $\mathrm{M}$ & $\mathrm{M}$ \\
\hline
\end{tabular}

H: High; M: Medium; L: Low; N: None.

*Economic values are related to current tourist use. Values were assessed adopting the procedure of Gray (2004).

Água Branca waterfall is situated on a fault scarp, hence its scientific and educational values are high. The importance and uniqueness of Serra do Mar are related to multiple attributes, making it one of the world's most important tropical scarps (Ab'Saber 1986). The Maranduba River of the Serra do Mar exhibits structural controls. The steep and deep valley contains many knick-points, which form rapids and waterfalls, such as Água Branca.

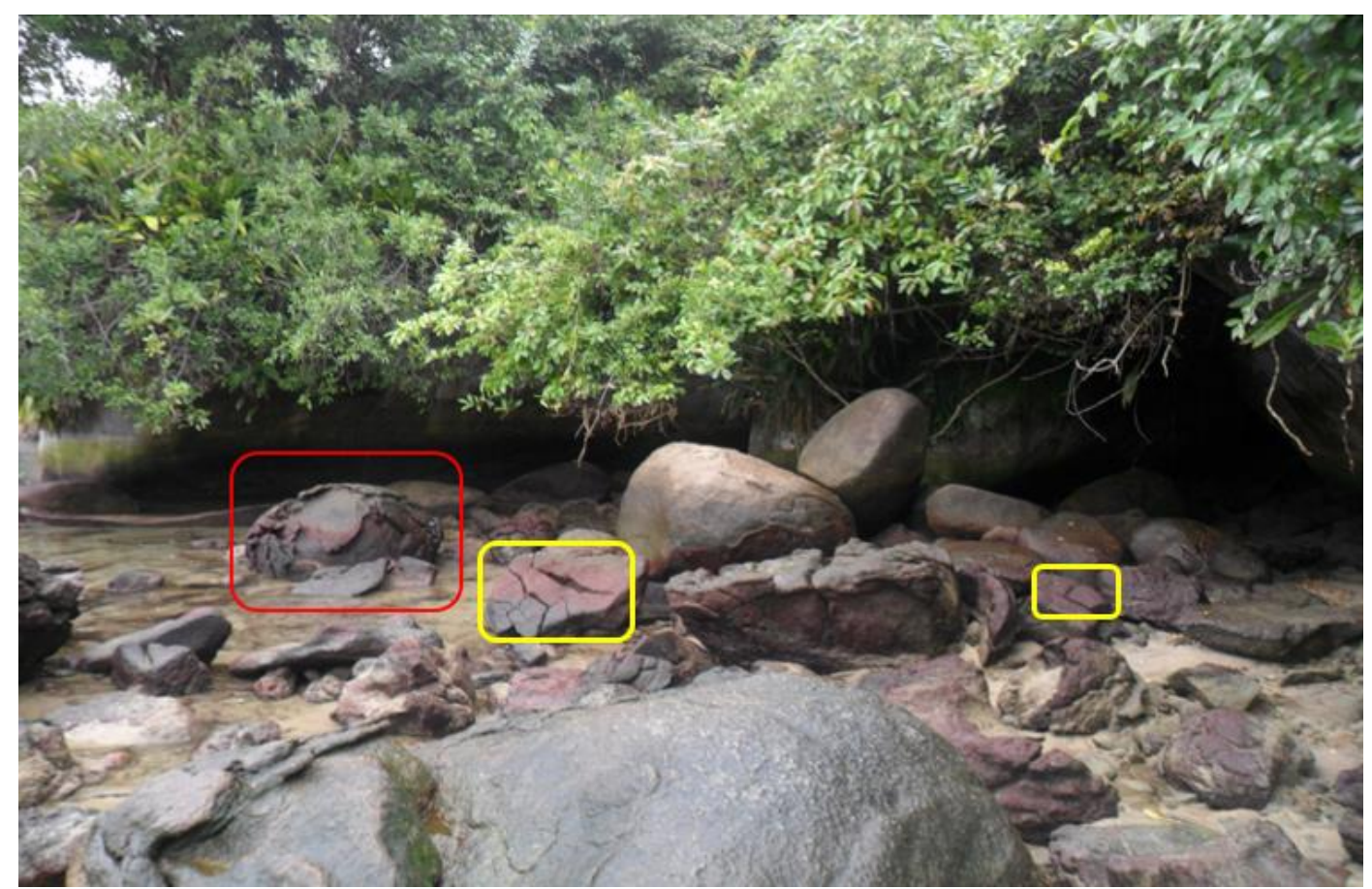

Fig. 5 Example of the scientific and educational potential of CANP, with examples of chemical weathering processes, such as spheroidal weathering (in red) and rock fractures (in yellow). Photo by L.A. Rangel (2016). 
Caixa D'Aço natural pool (CANP) has high intrinsic and aesthetic values, since it is a major tourist attraction. This is due to its great appeal to 'sun and sea' tourism, its scenic beauty and its importance for the local community. From environmental, historic and cultural perspectives Água Branca waterfall has high intrinsic, aesthetic and cultural values (Fig. 6). The cultural value of CANP is high because local people use the pool to store their canoes, when they cannot access the beach (Santos 2016, MMA 2002). Thus, the pool was directly associated with traditional fishing culture, emphasizing its historical-cultural importance.

The assigned functionality value is medium, considering the role of CANP in local ecosystem maintenance and fishing. The CANP environment is very sensitive to changes. There is no fishing in SBNP area, only in the buffer zone. On Água Branca trail it is possible to observe rich and diverse flora and fauna and bird-watching is very popular amongst both tourists and local people.

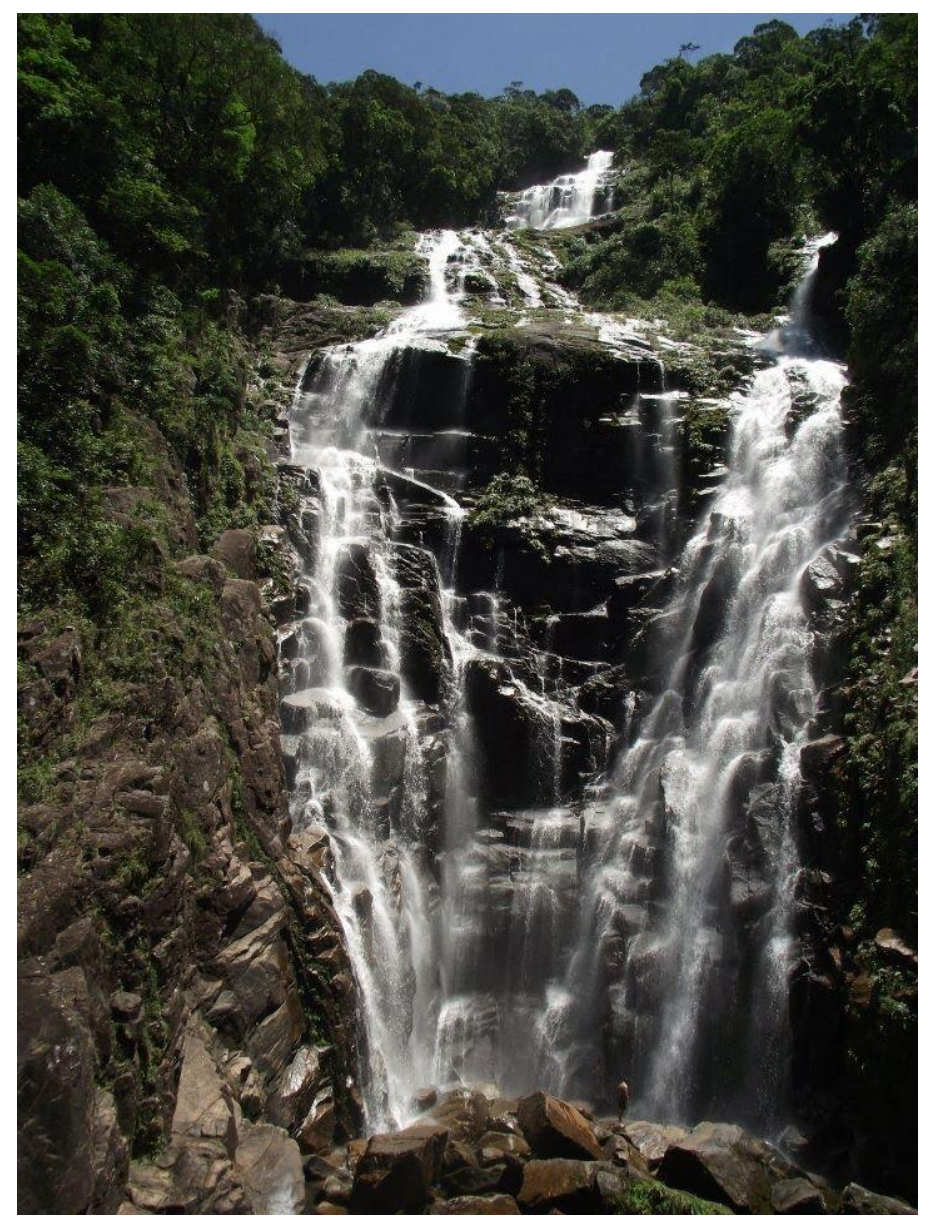

Fig. 6 Água Branca waterfall, which is the most attractive example of a geosite within Maranduba drainage basin. Photo by Roberto Oliveira. 
The $4.5 \mathrm{~km}$ long Água Branca trail starts at $70 \mathrm{~m}$ above sea-level, reaching an altitude of $560 \mathrm{~m}$. The terrain is difficult, with slope angles $\leq 60^{\circ}$, and soil erosion is evident on several parts of the trail. There are no information signs. The river must be crossed to reach the trail summit, which makes it even more difficult to complete the whole course. Caixa D'Aço natural pool trails start on Meio beach after crossing the Trindade River, which is polluted by village sewage. The trail difficulty level is medium, considering slope angles are $>20^{\circ}$, the presence of both soil erosion on the trails and degraded areas and the absence of management structures. Geodiversity services ecosystem analysis is presented in Table 5.

Geodiversity analyses assist in the identification and classification of sites of high value for educational, provisioning, cultural and regulatory services. Both sites were given no value for provisioning services, as Federal legislation forbids mineral exploitation within Protected Areas. The only value that was different between the two sites is support services, which for CANP is categorized as medium and Água Branca waterfall as high.

Table 5. Geodiversity services and main attributes evaluated in Caixa D'Aço natural pool trails (SBNP) and Água Branca trail (SMSP)

\begin{tabular}{|c|c|c|}
\hline Geodiversity Services & Caixa D'Aço natural pool trails & Água Branca trail \\
\hline Regulatory services & $\begin{array}{c}\text { High value. } \\
\text { Important for local water supply. } \\
\text { Caixa D'Aço pool is important } \\
\text { for local sea-water quality and } \\
\text { the conservation of fragile } \\
\text { marine species. }\end{array}$ & $\begin{array}{c}\text { High value. } \\
\text { Maranduba River is the } \\
\text { main water supply for } \\
\text { the surrounding } \\
\text { districts. }\end{array}$ \\
\hline Support services & $\begin{array}{l}\text { Medium value. } \\
\text { The pool is the habitat of marine } \\
\text { fauna and typical Atlantic forest } \\
\text { flora and fauna. }\end{array}$ & $\begin{array}{l}\text { High value. } \\
\text { On rocky slopes, formed } \\
\text { of Ubatuba green } \\
\text { granite (charnockite), } \\
\text { there are Atlantic forest } \\
\text { flora and fauna, } \\
\text { including orchids and } \\
\text { bromeliads. }\end{array}$ \\
\hline Provisioning services & $\begin{array}{l}\text { No value. } \\
\text { CANP is within a Conservation } \\
\text { Unit, which forbids mineral } \\
\text { exploitation. }\end{array}$ & $\begin{array}{l}\text { No value. } \\
\text { Água Branca geosite is } \\
\text { within a Conservation } \\
\text { Unit, which forbids } \\
\text { mineral exploitation. }\end{array}$ \\
\hline Cultural services & $\begin{array}{l}\text { High value. } \\
\text { The pool has high local }\end{array}$ & $\begin{array}{l}\text { High value. } \\
\text { The pool has high local }\end{array}$ \\
\hline
\end{tabular}




\section{Knowledge services}

\section{Conclusions}

The trails are being damaged by the impacts of trampling and erosion at the edge of paths. This edge erosion poses risks of slipping and accidents for visitors. Thus, it is necessary to recover degraded areas of the Caixa D'Aço natural pool and Água Branca trails. Appropriate approaches include adopting bioengineering techniques and installing more efficient management structures to impede further water erosion.

${ }^{2}$ PROMATA is the Association for the Preservation and Recuperation of the Atlantic Forest in Ubatuba. environmental quality. It is of high value for geotourism, ecotourism, leisure and environmental education. CANP has social development potential for local people, because it is linked with cultural and spiritual aspects of the Caiçara population. It is also important for fishing.

environmental quality. It is of high value for geotourism, ecotourism, leisure and environmental education It is a natural heritage, with great cultural, spiritual and historic significance.

It served as a transport route during the colonial period. The waterfall is visible from different parts of the drainage basin and is a local symbol.

\section{High value.}

The trails receive many visitors. Services include employment for local people (guides on the trails and boat transport for tourists). The trails are used for teaching geomorphology and geology. There is much potential for environmental education activities for tourists and the local community. These impacts require careful monitoring. number of visitors, survey is needed, to monitor its use, mainly due to the importance and rarity of the

Ubatuba green granite (charnockite). Its geological, geomorphological and hydrological characteristics allow the understanding of past processes (e.g. the Serra do Mar formation).

The PROMATA ${ }^{2}$ NGO promotes educational activities for both tourists and the local community, such as bird-watching. 
Geodiversity values were very similar at the two study areas, being different only for Economic and Scientific/Educational values. This is related to the higher economic value of Caixa $D^{\prime} A c ̧ o$ natural pool. Água Branca waterfall has higher scientific and educational value.

It is important to recognize the geological and geomorphological heritage of both Serra da Bocaina National Park (SBNP) and Serra do Mar State Park (SMSP). Thus, it is recommended that site managers identify and map geoheritage sites and disseminate information. These activities will help visitors both appreciate scenic landscapes and increase their understanding of environmental systems.

\section{References}

Ab'Saber AN (1986) O tombamento da Serra do Mar no Estado de São Paulo. Revista do Patrimônio Histórico e Artístico Nacional, São Paulo, 21:7-20.

An S, Darboux FE, Cheng M (2013) Revegetation as an efficient means of increasing soil aggregate stability on the Loess Plateau (China). Geoderma, 209:75-85.

Arshad MA, Martin S (2002) Identifying critical limits for soil quality indicators in agroecosystems. Agriculture, Ecosystems and Environment 88:153-160.

Avelar S, Vasconcelos C, Mansur KL, Anjos SC, Vasconcelos GF (2018) Targeting sustainability issues at geosites: a study in Região dos Lagos, Rio de Janeiro, Brazil. Geoheritage 10(1):1-9.

Barros A, Gonnet J, Pickering C (2013) Impacts of informal trails on vegetation and soils in the highest protected area in the Southern Hemisphere. Journal of Environmental Management, 127:50-60.

Bento LCM, Rodrigues, SC (2013) Geoturismo em unidades de conservação: uma nova tendência ou uma necessidade real? - estado da arte (2013). Revista do Departamento de Geografia - USP 25:77-97. http://www.revistas.usp.br/rdg/article/view/75175 Accessed 02 February 2019.

Brasil. (2000) Lei Federal No 9.985, de 18 de julho de 2000 - Criação do Sistema Nacional de Unidades de Conservação (SNUC). http://www.planalto.gov.br/ccivil 03/leis/19985.htm Accessed 02 February 2019.

Bright JA (1986) Hiker impact on herbaceous vegetation along trails in an evergreen woodland of Central Texas. Biological Conservation, 36:53-69.

Brilha J (2016) Inventory and quantitative assessment of geosites and geodiversity sites: A Review. Geoheritage, 8(2):119-134.

Cole, DN (1993) Minimizing conflict between recreation and nature. In: Smith DS, Hellmund PC (eds) Ecology of Greenways: Design and Function of Linear Conservation Areas, University of Minnesota Press, Minneapolis, pp. 105-122. 
Cole DN, Schreiner GS (1981) Impacts of backcountry recreation: site management and rehabilitation - an annotated bibliography. General Technical Report INT-121. US Dept. of Agriculture, Forest Service, Rocky Mountain Research Station, Fort Collins, pp. 58.

Cole DN, Landres PB (1996) Threats to wilderness ecosystems: impacts and research needs. Ecological Applications, 6:168-184.

Conti BR, Irving MA (2014) Desafios para o ecoturismo no Parque Nacional da Serra da Bocaina: o caso da Vila de Trindade (Paraty, RJ). Revista Brasileira de Ecoturismo, São Paulo, 7(3):517-538.

Conway, J.S. (2010) A soil trail? A case study from Anglesey, Wales, UK. Geoheritage, 2(1):15-24.

Cruz O (1974) A Serra do Mar e o litoral na Área de CarÁguatatuba-SP: Contribuição a Geomorfologia Litorânea Tropical. São Paulo, pp 167. Tese (Doutorado), Faculdade de Filosofia, Letras e Ciências Humanas, Universidade de São Paulo.

Doran JW, Parkin TB (1994) Defining and assessing soil quality. In: Doran JW, Coleman DC, Bezdicek DF, Stewart BA (eds). Defining soil quality for a sustainable environment. Soil Science Society of America Journal. Madison, Special Publication. 35:3-22.

Doran JW, Jones AJ (1996) Methods for assessing soil quality. Soil Science Society of America Journal. Madison, Special Publication.

Dowling, R (2009) Geotourism's contribution to Local and Regional Development. In: Neto de Carvalho, C and Rodrigues, JC (eds), Geoturismo \& Desenvolvimento Local, Idanha-aNova, São Paulo, pp. 15-37.

Dowling, RK (2010) Geotourism's global growth. Geoheritage, 3(1):1-13.

Dowling, RK (2013) Global geotourism - an emerging form of sustainable tourism. Czech Journal of Tourism, 2(2):59-79.

EMBRAPA (2011) Manual de métodos de análise de solo. Rio de Janeiro: Centro Nacional de Pesquisa de Solos. Documentos, 212p.

Figueiredo M do A, Assis Brito I, Takeuchi RC, Almeida-Andrade M, Vieira Rocha CT (2010) Compactação do solo como indicador pedogeomorfológico para erosão em trilhas de unidades de conservação: estudo de caso no Parque Nacional da Serra do Cipó, MG. Revista de Geografia. Recife: UFPE - DCG/NAPA, Vol. especial VIII SINAGEO, 3:236-247.

Folmann, AC, Pinto, MLC, Guimarães, GB (2010) Trilhas interpretativas como instrumentos de geoturismo e geoconservação: O caso da trilha do Salto São Jorge, Campos Gerais. GEOUERJ, 2(21):267-286.

Forte JP, Brilha J, Pereira DI, Nolasco M (2018) Kernel density applied to the quantitative assessment of geodiversity. Geoheritage, 10(2): 205-207 
Fullen MA, Catt JA (2004) Soil Management: Problems and Solutions, Arnold, London.

Gray M (2004) Geodiversity: valuing and conserving abiotic nature, John Wiley and Sons, Chichester.

Gray M (2005) Geodiversity and Geoconservation: What, Why, and How? In: Gray M. Geodiversity \& Geoconservation. The George Wright Forum 22(3):4-12.

Gray M (2008) Geodiversity: developing the paradigm. Proc Geol Assoc 119(3-4):287-298. https://doi.org/10.1016/S0016-7878(08)80307-0 Accessed 02 February 2019.

Gray M (2013) Geodiversity — Valuing and Conserving Abiotic Nature, 2nd edn. John Wiley and Sons, New York.

Guerra AJT, Jorge MCO, Fullen MA, Bezerra JFR (2013) The gomorphology of Angra dos Reis and Paraty municipalities, Southern Rio de Janeiro State. Revista Geonorte, 9(1):1-21.

Hammitt WE, Cole DN (1998) Wildland Recreation: Ecology and Management. 2nd edn. John Wiley \& Sons, New York, pp. 361.

Hasui Y, Haralyi NLE, Costa JBS (1993) Megaestruturação pré-cambriana do território brasileiro baseada em dados geofísicos e geológicos. Geociências, 12:7-31.

Hose TA (2006) Geotourism and interpretation. In: Dowling RE, Newsome D (eds.) Geotourism. Elsevier Butterworth Heinemann, Oxford.

IBGE (2010) Censo Demográfico. https://www.ibge.gov.br/ Accessed 02 February 2019.

Jewell MC, Hammitt WE. (2000) Assessing Soil Erosion on Trails: A Comparison of Techniques. In: USDA Forest Service Proceedings RMRS, 5:133-140.

Jorge, MCO Mendes IA, Sato SE (2003) Caracterização Pluviométrica do Município de Ubatuba: Período de 1978 a 1999. In: X Simpósio Brasileiro de Georafia Física Aplicada, Rio de Janeiro. Anais do X Simpósio Brasileiro de Geografia Física Aplicada.

Jorge MCO, Guerra AJT (2016) Geodiversidade, Geoturismo e Geoconservação: Conceitos, Teorias e Métodos. Revista Espaço Aberto 6(1):151-174.

https://revistas.ufrj.br/index.php/EspacoAberto/article/view/5241 Accessed 02 February 2019.

Jorge MCO, Guerra AJT, Fullen MA. (2016) Geotourism, geodiversity and geoconservation in Ubatuba Municipality, São Paulo State, Brazil. Geography Review, 29:26-29.

Jorge MCO (2017) Potencial geoturístico e estratégias de geoconservação em trilhas situadas na região sul do município de Ubatuba - SP. Tese de doutorado, Programa de Pósgraduação em Geografia, UFRJ, 229p.

Kubaliková, L (2013) Geomorphosite assessment for geotourism purposes. Czech Journal of Tourism, 2:80-104.

Kutiel P, Zhevelev H, Harrison R (1999) The effect of recreational impacts on soil and vegetation of stabilized coastal dunes in Sharon Park, Israel. Ocean and Coastal Management, 42:1041-1060. 
Lal R (1997) Degradation and resilience of soils. Philosophical Transactions of the Royal Society B: Biological Sciences 352:997-1010.

Leung Y, Marion JL (1996) Trail degradation as influenced by environmental factors: A state-of-knowledge review. Journal of Soil and Water Conservation 51(2):130-136.

Leung Y, Marion, JL (1999) The influence of sampling interval on the accuracy of trail impact assessment. Landscape and Urban Planning, 43(4):167-179.

Lopes LSO, Araújo JL, Castro AJF (2011) Geoturismo: Estratégia de Geoconservação e de Desenvolvimento Local. Caderno de Geografia, 21(35):37-51.

Lynn NA, Brown RD (2003) Effects of recreational use impacts on hiking experiences in natural areas. Landscape and Urban Planning, 64:77-87.

Magro TC (1999) Impactos do uso público em uma trilha no planalto do Parque Nacional do Itatiaia. 151f. Tese (Doutorado) - Escola de Engenharia de São Carlos, Universidade de São Paulo. São Carlos.

Marion JL, Leung Y (2001) Trail resource impacts and an examination of alternative assessment techniques. Journal of Park and Recreation Administration, 19(3):17-37.

Marion JL, Cole DN (1996) Spatial and temporal variation in soil and vegetation impacts on campsites. Ecological Applications, 6(2):520-530.

Ministério do Meio Ambiente (MMA). (2002) Plano de Manejo do Parque Nacional da Serra da Bocaina. Instituto Brasileiro de Meio Ambiente. Brasília: Ministério do Meio Ambiente. http://www.icmbio.gov.br/parnaserradabocaina/extras/.html. Accessed 02 February 2019.

Mittermeier RA, Gil PR, Hoffmann M, Pilgrim J, Brooks T, Mittermeier CG, Lamourex J, Fonseca GAB (2005) Hotspots Revisited. Earth's Biologically Richest and Most Endangered Terrestrial Ecorregions. CEMEX.

https://www.conservation.org/global/brasil/publicacoes/Documents/HotspotsRevisitados.pdf

Accessed 02 February 2019.

Monteiro CA de F (1973) A dinâmica climática e as chuvas no Estado de São Paulo. USP/IGEOG, São Paulo.

Moreira JC (2010) Geoturismo: uma abordagem histórico-conceitual. Turismo e Paisagens Cársticas, 3(1):5-10.

Morgan RPC (2005) Soil Erosion and Conservation. Blackwell, London

Nascimento MAL, Mansur KL, Moreira, JC (2015) Bases conceituais para entender geodiversidade, patrimônio geológico, geoconservação e geoturismo. In: XVI Simpósio Brasileiro de Geografia Física Aplicada, Teresina, 28 June-4 July 2015.

Nepal SK, Amor-Nepal SA (2004) Visitor impacts on trails in the Agarmatha (Mt. Everest) National Park, Nepal, Ambio (Journal of the Royal Swedish Academy of Sciences) 33(6): 334-340.

Nepal S (2003) Trail impacts in Sagarmatha National Park. Environmental Management, 32:312-321.

Newsome D, Dowling R. (2006) Geotourism. Elsevier Butterworth-Heinemann, Oxford. 
Ostanello MCP, Danderfer A, Castro PTA. (2013). Caracterização de lugares de interesse geológico e trilhas geoturísticas no Parque Estadual do Itacolomi - Ouro Preto e Mariana, Minhas Gerais. Revista Geociências UNESP, 32(2):286-297.

Pereira LS, Rodrigues AM, Jorge MCO, Guerra AJT, Fullen MA (2016) Processos hidroerosivos em solos degradados em relevo de baixa declividade. Revista Brasileira de Geomorfologia, 17(2):299-316.

Ponçano WL, Carneiro CDR, Bistrichi CA, Pires Neto AG, Santos MCSR, Almeida MA, Almeida FFM (1980) Carta Geomorfológica do Estado de São Paulo na escala de 1:2,500,000 com base no conceito de sistemas de relevo. In: Congr. Bras. Geol., 31, Baln. Camboriú, 1980. Anais... Balneário Camboriú: SBG. 2:1013-1015.

Rangel LA (2014) O Impacto da Utilização de Trilhas na Área de Proteção Ambiental de Cairuçu - Paraty - Rio de Janeiro. Dissertação (Mestrado) Universidade Federal do Rio de Janeiro, Instituto de Geociências, Rio de Janeiro, pp. 184.

Rangel LA, Guerra AJT (2018) Microtopografia e compactação do solo em trilhas geoturísticas no litoral do Parque Nacional da Serra da Bocaina - estado do Rio de Janeiro. Revista Brasileira de Geomorfologia. 19(2):391-405.

Reichert JM, Reinert DJ, Braida JA (2003) Qualidade dos solos e sustentabilidade de sistemas agrícolas. Revista Ciência e Ambiente 27:29-48.

Santos LB (2016) Percepção ambiental e conflitos de uso dos recursos naturais em áreas protegidas: um estudo no Parque Nacional da Serra da Bocaina. Tese (Doutorado em Geografia) - Departamento de Geografia, Universidade Federal do Rio de Janeiro, Rio de Janeiro.

Serrano E, Gonzales-Trueba, J. (2005) Assessment of geomorphosites in natural protected areas: the Picos de Europa National Park (Spain). Géomorphologie: relief, processus, environnement, 31(3):197-208.

SMA-SP (2008) Secretaria do Meio Ambiente do Estado de São Paulo. Plano de Manejo do Parque Estadual da Serra do Mar: Secretaria do Meio Ambiente, Instituto Florestal, Divisão de Reservas e Parques Estaduais. São Paulo: SMA, 2008.

Smets T, Poesen J, Bhattacharyya R, Fullen MA, Subedi M, Booth CA, Kertész A, Szalai Z, Tóth A, Jankauskas B, Jankauskiene G, Guerra AJT, Bezerra JFR, Zheng Yi, Panomtarachichigul M, Bühmann C, Paterson, DG (2011). Evaluation of biological geotextiles for reducing runoff and soil loss under various environmental conditions using laboratory and field plot data. Land Degradation \& Development. 22:480-494.

Takahashi L (1998) Caracterização dos visitantes, suas preferências e percepções e avaliação dos impactos da visitação pública em duas unidades de conservação do estado do Paraná. 129f. Tese (Doutorado) - Faculdade de Ciências Agrárias, UniversidadTHEe Federal do Paraná. Curitiba.

USDA (United States Department of Agriculture) (2015)

https://www.nrcs.usda.gov/wps/portal/nrcs/main/soils/survey/

Accessed 02 February 2019. 
Wolf ID, Croft DB (2014) Impacts of tourism hotspots on vegetation communities show a higher potential for self-propagation along roads than hiking trails. Journal of Environmental Management, 143:173-185. 